\title{
Audit Committee, Board, and Audit Report Lag
}

\author{
Ahmad Iskandar Rahmansyah, Siti Maria Wardayati, Muhammad Miqdad \\ Department of Accounting, University of Jember \\ Email: iskandar.rahmansyah@gmail.com
}

\section{A R T I C L E I N F O}

Received:

7 January 2021

Revised:

3 March 2021

Accepted:

9 March 2021

\begin{abstract}
A B S T R A C T
Effect of corporate governance being the crucial issue in growing process of audit financial statement in order to decrease audit report lag. Some of previous studies stated that correlation between corporate governance and audit report lag is not consistence. That is why, this study used variable control as firm and auditor characteristics in order to find out the effect of audit committee and board characteristics to audit report lag. The variable independent consist of audit committee size, audit committee independent, board size, board independent, and board meeting, meanwhile the variable control consists of firm size, loss, and quality auditor. Sample of this study is 55 firms in BEI around 20172018 periods. The annual financial statement data gotten from BEI official, and analyzed by using multiple regression model. The result showed that only board size has significant effect to audit report lag, while audit committee size, audit committee independent, board independent, and board meeting variables have do not have significant effect to audit report lag.
\end{abstract}

Keywords: Audit Report Lag, Audit Committee and Board

Cite this as: Rahmansyah, A. I., Wardayati, S. M., Miqdad, M. (2020). Audit Committee, Board, and Audit Report Lag. Wiga : Jurnal Penelitian Ilmu Ekonomi, 11(1), 19-30. https://doi.org/10.30741/wiga.v11i1.577

\section{INTRODUCTION}

Capital market is a place for buying and selling financial instruments in long-term, such as stocks, bonds, etc (Darmadji dan Fakhruddin (2015); Serfiyani at el. (2017)). One of financial instruments that are interested in is stocks because of flexible and easy for transaction. Before doing transaction for that stock, the investor need information about the firms through financial report. The investor's limited information have on the firms is inversely proportional with information who is had by management. The information gap is related to agency theory is called information asymmetry.

Agency theory is relationship between agents and principles who work together (Supriyono, 2018). Information asymmetry between firm's management and investor can lead to misuse information for their business itself. As the result, the investor get mislead information and lead to 
errors in making decisions. One of the way to reduce information asymmetry is require the firms to implement the corporate governance. The corporate governance will create new organization in the firms such as board and audit committee. The aim of two organizations is to bridge the principal business to the agent, especially related to financial report. Published financial reports should have quality information that information are relevance, timeliness, and accuracy, so can be used for making right decisions by stakeholders (Yakub, 2012).

In the capital market, stakeholders are not only investors, but there are government, workers, societies etc. In stakeholder theory, the firms have social responsibilities not only for the investor but also for all stakeholders including government, workers, societies etc. (Ulum, 2017). The firms should responsible to government because capital market arranged and supervised by the government. The government of Indonesia that has a duty is Otoritas Jasa Keuangan (OJK). All of firms should obey the regulation that made by OJK to continue their capital market.

The importance of financial statement as one of the information for the investor ask the OJK to make some regulations about financial statement and corporate governance. OJK's regulation about financial statement is POJK No.29/PJOK.04/2016. Based on that regulation, it is determined financial statements must be reported no later than the end of March or have a time limit of 90 days after the closing date of the book. If the firms are late, they will given punishment whether warning letter, paying sum of fines to the revocation of the company name from the Indonesian capital market (IDX) which better known as delisting. Furthermore, in the regulation determine that financial statements that published by firms are audited financial statements that are audited by external auditor. This is arranged in order stakeholders know their level of material errors and the fairness of financial statements itself. In other hand, external auditor can give stakeholder independent security that accounting information is reliable, relevant and accountable (Scot \& Gist, 2013). The time used by the auditor for completing audit financial statements known Audit Report lag (ARL) term. ARL measured as the difference between signing date of the audit report and the end date of the financial reporting period (Habib et al., 2019; Abernathy et al., 2017; Durand, 2019; Abdillah et al., 2019; Ayemere and Elijah, 2015). The longer of ARL means that financial statement takes long time for publishing. The effect of long time publication makes stakeholders thought that there is problem in the firms so auditing process need long time. Furthermore, it makes the financial statement is out of date so that it can reduce value of financial statements itself.

To reduce asymmetry and ARL problems, OJK issued regulations about corporate governance, they are POJK No.55/POJK.04/2015 about audit committee and POJK No.57/POJK.04/2017 about board. Based on POJK No.55/POJK.04/2015, audit committee is part of the firms that formed by board and their duty are assist the implementation of board commissioner's functional. Based on POJK No.57/POJK.04/2017, board are part of the firms whose job is to supervise and advise the directors. The function of board as communicators among parties that related to auditing process and reporting of financial statements (Sultana et al., 2015). So, it can be concluded that the existence of audit committee and board can reduce asymmetry and process of auditing get smoothly that carried out by the auditors in order to reduce ARL.

Beside audit committee and board, other factors can affect ARL. Habib et al., (2019) divided the factors into three parts, the first, variables related to auditor characteristics; the second, corporate governance; and the third, the firm characteristics. In this research, the researcher used research of Habib et al., (2019) that divided ARLs' factors into three parts; they are auditor characteristics (Big 4), corporate governance (audit committee and board); and firm characteristics (loss, firm size). It is because in capital market, there are three sectors involved in, the first, auditor as determinant whether the financial statements by the firms is right or false; the second, the firms as agents that sell their stocks; and the third, the principal represented by the existence of corporate governance on the firms itself. In this research, the researcher divides this corporate governance 
into two variable, they are the audit committee and board characteristics as independent variables, and the firms and auditors characteristics as controlling variables.

The audit committee characteristics in this research are audit committee size and audit committee independent. The first variable is audit committee size (AC.SIZE) is the total of audit committee variables that can affect ARL. This confirmed by the research of Nehme et al. (2015) who examined the effect of AC.SIZE and ARL using a sample of firms on the London Stock Exchange. The study indicated that there are significant effects of AC. SIZE and ARL. Raweh et al. (2019) and Aslam et al. (2017) added that AC.SIZE and ARL have significant effects. Contrary of that, Karout et al. (2020) and Oussii \& Taktak (2018) indicated that there is no significant effect of AC.SIZE and ARL. The second variables is audit committee independent (AC.INDP) is number of audit committee independent ratios that owned by the firms and this variable can affect ARL. This proved at Aslam et al. (2017) who examined the effects of AC.INDP to ARL through 944 sample of firms on the Pakistan and Karachi Stock Exchanges. The result stated that AC.INDP significant affect to ARL. Nehme et al. (2015) and Durand (2019) supported about the significant effect of AC.INDP and ARL. Contrary of Aljaadi et al. (2015) and Firnanti \& Karmudiandri (2020) that indicated there is no significant effect of AC.INDP and ARL.

The board characteristics in this research is board size, board independent, and board meeting. The first variable is board size (B.SIZE) which is total of board in the firm and this variable can affect ARL. This evidenced by Sakka \& Jarboui (2015) which conducted research on the effect of B.SIZE on ARL with a sample of issuers on the Tunis Stock Exchange. This study indicated significant effect of B.SIZE on ARL. Al Daoud et al. (2015) and Al Fraih (2016) supported that there is significant effect between B.SIZE and ARL. In other hand, it is not appropriate with Durand, G. (2019) and Habib et al. (2019) research that indicated that there is no significant effects of B.SIZE on ARL. The second variables is board independent (B.INDP) which is number of board independent ratio in the firm and can affect ARL. Based on Al Fraih (2016) who conducted research on the effect of B.INDP on ARL with a sample of 174 firms in KSE. This research indicated significant effect between B.INDP and ARL. Firnanti \& Karmudiandri (2020) and Habib et al. (2019) agree that B.MEET has a significant effect on ARL. In other hand, it is not appropriate with Kaaroud et al. (2020) and Sari (2019) research that indicated that there is no significant effects of B.INDP on ARL. The third variables is board meeting (B.MEET) which is intensity board meeting in a year and this variabel can affect ARL. It is appropriate with research of Al Daoud et al. (2015) who conducted the effect of B.MEET and ARL through sample Jordanias' firm on the Amman Stock Exchange. The study indicated that there is significant effects B.MEET and ARL. Firnati et al. (2020) support that B.MEET has a significant effect on ARL. In other hand, it is not appropriate with Habib et al. (2019) and Nehme (2015) research that indicated that there is no significant effects of B.MEET on ARL.

Firm characteristics in this research is firm size and loss that can affect ARL. Kaaroud et al. (2020), Hasballah \& Ilyas (2019), Nehme et al. (2015) and Azzami \& Salehi (2017) used firm size (F.SIZE) as controlling variable. Their research indicated that there is significant effect of F.SIZE on ARL. Al Jaaidi et al. (2015), Azami \& Salehi (2017), Hussin et al. (2018), and Baatwah et al. (2019) used loss (LOSS) as controlling variable. Their finding is same that indicated there is significant effect of LOSS on ARL. Furthermore, auditor characteristics in this research is auditor quality that can affect ARL. Sultana et al. (2015), Ocak \& Ozden (2018), Hussin et al. (2018), dan Ghafran \& Yasmin (2018) research used auditor quality (BIG 4) as controlling variable. This research indicated that there is significant effect (BIG 4) on ARL.

In this research, the researcher will analyze the effect of audit committee and board characteristics on ARL through characteristics firm and auditor as controlling variable. The researcher though that audit committee and board are part of corporate governance which is bridge of between stakeholder business with the firm, so information asymmetry can be reduced. Furthermore, there is inconsistency from the results of previous studies being the reason of researcher use this 
variable. Sample of this research is financial sector of the firms on the IDX in 2017-2018. The reason of using this financial sector firms because this sector has important role in economics' country, considering that main function as the supplier funds in economics. The importance of financial sector attracts researchers to find out more about the role of the audit committee and board characteristics in the issuer in relation to the length of the audit process carried out by the auditor.

State of the art of this research with previous research lies in the type of variable and the sample used. In this study, the researcher used audit committee and board characteristics together as independent variable and firms and auditor characteristics as controlling variable. Those variable are used together to test their effect on ARL. Whereas previous studies only used one independent variable, such as research by Salleh et al. (2017), Baatwah et al. (2019), Ghafran \& Yasmin (2018), Sultana et al. (2015), Aljaaidi et al. (2015), Aslam et al. (2017), and Raweh (2019) which only use the audit committee characteristic variable as an independent variable, and Alfraih's (2016) research which only uses the board characteristic variable as an independent variable. Not only that, there are also previous studies that did not use control variables, such as research by Al Daoud et al. (2015), Sakka and Jarboui (2015), Firnanti and Karmudiandri (2020), and Aslam et al. (2017). Furthermore, this study uses a sample of financial sector firms on the IDX. While, previous study Al Daoud et al. (2015), Sakka and Jarboui (2015), Nehme et al. (2015), Ocak and Ozden (2018), Hasballah and Ilyas (2019), Raweh et al. (2019), and Sari et al. (2019) excluded the financial sector as a sample in their research.

The effects between audit committee size and ARL. The research of Habib et al. (2019); Nehme et al. (2015); Raweh (2019); Durand, G. (2019); Firnanti and Karmudiandri (2020); Aslam et al. (2017); Sari et al. (2019) indicated a significant effect of AC.SIZE with ARL. Nehme et al. (2015) argued that a large number of audit committees means that the resources they have are also more, so errors in financial reports could be resolved in a short time. Habib et al. (2019) also argued that a larger number of audit committees would affect on the amount of resources they have, so it can reduce delays in the completion of financial statements and can shorten ARL. Based on this assessment, then Hypothesis 1 (H1): there is an effect between audit committee size and ARL on financial sector firms on the IDX.

The effects between audit committee independent and ARL. Nehme et al. (2015); Durand, G. (2019); Aslam et al. (2017); Sultana, et al. (2015) researchs indicated that AC.INDP had a significant effect on ARL. The more ratio of audit committee independent members than audit committee non-independent in firms, so it can reduce ARL of the firms. The aim of an audit committee independent is audit committee can be objective to carry out their function without pressure from any party. The optimal performance of the audit committee members implies that their duty to assist the board in firms' control and speed up the reporting time of audited financial statements will achieved. Based on that explanation, Hypothesis $2(\mathrm{H} 2)$ : there is an effect between the audit committee independent and ARL on financial sector firms on the IDX.

The effects between board size and ARL. Al Daoud et al. (2015); Nehme et al. (2015); Sakka and Jarboui (2015); Alfraih, MM (2016); Firnanti and Karmudiandri (2020); indicated a significant effect of B.SIZE on ARL. According to Al Daoud et al. (2015) number of board independent in a firm can shorten ARL. Sakka and Jarboui (2015) stated that many board, make it stronger in supervising, eliminating, and facilitating auditors in carrying out the audit process. Nehme et al. (2015) argued that the more board, the responsibility will be less for each board. It makes auditor easier to communicate in related to audit process. Good communication will reduce ARL. Based on that explanation, Hypothesis $3(\mathrm{H} 3)$ : there is an effect between the board size and ARL on financial sector firms on the IDX.

The effects of board independent and ARL. Firnanti and Karmudiandri (2020), Al Daoud et al. (2015); Habib et al. (2019); Durand, G. (2019); Alfraih, MM (2016), indicated that there is a 
significan effect between B.INDP and ARL. Sakka and Jarboui (2015) argued that board independent has an objective decision. It can prevent auditor from carrying out the audit process. The worst thing might happen in changing the financial statements / auditor's opinion. Habib et al. (2019) argued that the board independent demands a quality audit to maintain their good name. The high of audit quality can be shorten ARL. Based on that, Hypothesis 4 (H4): there is an effect between the board independent and ARL on financial sector firms on the IDX.

The effects of board meeting and ARL. Firnanti and Karmudiandri's research (2020); Al Daoud et al. (2015) indicated that there is a significant effect between B.MEET and ARL. Al Daoud et al. (2015) argued that number of board meeting could reduce delays in completion of financial statements and reduce ARL. Habib et al. (2019) added that the high intensity of the board meeting will increase supervision and ensure the timely submission of audited financial statement, thereby reducing Audit Report Lag (ARL). Based on this explanation, Hypothesis 5 (H5): there is an effect between the board meeting and ARL on financial sector firms on the IDX.

\section{METHOD}

All of the firms on IDX are population of this study, while the sample is financial sector firms on IDX 2017-2018 period. The requirement used for making decision is financial sector firms on the IDX that are active during 2017-2018 and financial sector firms that reported annual reports for 2017-2018 on the IDX. Furthermore, only 55 firms in the financial sector full in these criteria, so the total of samples used are 110 firms.

Audit report lag is dependent variable. Based on Oussii \& Taktak (2018); Alfraih (2016); Baatwah et al. (2019); and Hussin et al. (2018) research, ARL could be calculated through deviation in days between the date of financial statemen and the audit report. Audit commitee size, audit commitee independent, board size, board independent, and board meeting are independent variables. Based on Hussin et al. (2018); Oussii \& Taktak (2018); and Habib et al. (2019) research, the audit committee size could be calculated through number of all members of audit committee. According to Hussin et al. (2018), the audit committee independent could calculated through the number of audit committee independent ratio to the total members of the audit committee. Based on Habib et al. (2019); and Alfraih (2016) research, board size could be calculated through number of all board members. Based on Habib et al. (2019); and Alfraih (2016) research, board independent could be calculated through number of board independent ratio to the total board members. Based on Habib et al. (2019) research board meetings could be calculated through number of board meeting in one year.

Firm size, loss, and auditor quality are control variables. Based on Habib et al. (2019); Baatwah et al. (2019); Alfraih (2016); and Hussin et al. (2018) research, firm size can be measured from total assets of the company during the study period. Based on Habib et al. (2019); Baatwah et al. (2019); and Hussin et al. (2018) research, loss can be measured through giving number 1 if the company reports a loss at the end of the accounting period and 0 if it reports profit at the end of the accounting period. Based on Habib et al. (2019); Baatwah et al. (2019); and Hussin et al. (2018), quality auditor can measured by giving the number 1 if it uses BIG 4 and 0 if it does not use BIG 4.

The data analysis method examines the effect of independent variables and ARL by using control variables is multiple regression. This regression used two different analysis models. The following an explanation of two models: The first model is a model that does not use control variables in statistical process. In this model will know the result of multiple linear regression without a control variable. The following statistical equations of model 1: ARL1 $=\beta 0+\beta 1$.AC.SIZE $+\beta 2$.AC.INDP $+\beta 3$. B.SIZE $+\beta 4$.B.INDP $+\beta 5$.B.MEET $+\mathrm{e}$ 
The second model is a model that uses control variables in statistical process. In this model will know whether the results of multiple linear regression is change after adding controlling variable. The controlling variable is an independent variable that not examined in the study, so it does not need to be included in the hypothesis (Chandrarin, 2017). The following is the statistical equation of model 2: ARL2 $=\beta 0+\beta 1$.AC.SIZE $+\beta 2$.AC.INDP $+\beta 3$.B.SIZE $+\beta 4$.B.INDP $+\beta 5$.B.MEET + $\beta 6 . \mathrm{F} . \mathrm{SIZE}+\beta$ 7.LOSS $+\beta 8 . \mathrm{BIG} 4+\mathrm{e}$

\section{RESULTS AND DISCUSSION}

Table 1. Descriptive Statistics Results

\begin{tabular}{lcccc}
\hline & $\mathbf{N}$ & Minimum & Maximum & Mean \\
\hline AC.SIZE & 110 & 2 & 6 & 3,41 \\
AC.INDP & 110 & 33 & 75 & 62,75 \\
B.SIZE & 110 & 2 & 10 & 4,13 \\
B.INDP & 110 & 17 & 75 & 50,45 \\
B.MEET & 110 & 2 & 57 & 9,17 \\
F.SIZE & 110 & 12 & 29 & 17,25 \\
LOSS & 110 & 0 & 1 & 0,17 \\
BIG4 & 110 & 0 & 1 & 0,38 \\
ARL & 110 & 22 & 89 & 67,22 \\
Valid N (listwise) & 110 & & & \\
\hline
\end{tabular}

Source: SPSS

Audit committee characteristics consist of two variables. The first variable, Audit Committee Size. The table shows that the financial sector firms have an average three (3) people of AC.SIZE. The maximum and minimum AC.SIZE values are two (2) people and six (6) people. The firms has an average number of audit committees are 3 people, according to POJK consisting of one who serves as chairman of audit committee and the rest as audit committee members. This audit committee will assist the functions board. The second variable, Audit Committee Independent. The table shows that financial sector firms have an average $62 \%$ of AC.INDP. The maximum and minimum AC.INDP values are $75 \%$ and $35 \%$. It means that audit committee independent has a larger portion in firms, so expected can work professionally and minimize the chances of fraud that will occur in a firm.

Board characteristics consist of three variables. The first variable, Board Size. The table shows that the financial sector firms have an average four (4) people of B.SIZE. The maximum and minimum B.SIZE values are 2 people and 10 people. The firms has an average number of board are four (4) people, according to POJK who will supervise and advise the director in the management of company. In order to be more effective and efficient in carrying out their duties, the board is required to make an audit committee. The second variable, Board Independent. The table shows that the financial sector firms have an average $50.45 \%$ of B.INDP. The maximum and minimum B.INDP values are $75 \%$ and $17 \%$. It means that independent board has a larger portion in the firms. The third variable, Board Meeting. The table shows that the financial sector firms have an average (nine) 9 times of B.MEET. The maximum and minimum B.MEET values are 57 times and 2 times. It means that the average meeting held is 9 times in one year, in accordance with POJK that requires a minimum 4 times of a year.

Firm characteristics consist of two variables. The first variable, Firm Size. From the table the results of descriptive statistics show that the financial sector issuers have an average is 17 logarithmic values of F.SIZE. The maximum and minimum F.SIZE values are 29 and 12 of logarithmic values. APIC is the firms with the most total assets is Rp. 2,393,353,176,663,000, -, while JMAS is the issuer with the least total assets is Rp. 166,267,000, -. The second variable, Loss. The table shows that the firms of the financial sector have 1 and 0 of maximum and 
minimum values. It means that some firms of the financial sector have experienced losses and some have benefited. In 2017, 45 out of 55 firms benefited, while 10 other firms suffered losses. In 2018 period, 55 and 46 firms are benefited, while 9 other firms are losses.

Auditor characteristic in this research is Quality Auditor. The table shows that the firms of the financial sector have 1 and 0 of maximum and minimum values of BIG 4 . It means that some financial sector firm use KAP Big 4 services in audit process of their financial statements and some are not. In 2017 period, 22 out of 55 firms used KAP big 4, while 33 firms used KAP except BIG 4 to audit their financial statements. In 2018 period, 20 out of 55 firm used KAP BIG4, while 35 firms used KAP except BIG 4 to audit their financial statements. Audit Report Lag. The table shows that financial sector firm have an average 67 days of ARL. The maximum ARL values are 89 days and 22 days. It means that the average of time are needed the firm to sign the audited financial statements is 67 days.

Table 2. F Test Result

\begin{tabular}{clccccc}
\hline Model & & Sum of Squares & df & Mean Square & F & Sig. \\
\hline \multirow{2}{*}{1} & Regression & 5926,016 & 5 & 1185,203 & 3,588 & 0,005 \\
& Residual & 34356,748 & 104 & 330,353 & & \\
& Total & 40282,764 & 109 & & & \\
\hline 2 & Regression & 11688,608 & 8 & 1461,076 & 5,161 & 0,000 \\
& Residual & 28594,155 & 101 & 283,11 & & \\
& Total & 40282,764 & 109 & & & \\
\hline
\end{tabular}

\section{Source: SPSS}

It known in model 1 , the magnitude of significance is 0.005 . Because it is less than 0.05 , means that there is a significant effect simultaneously between the independent and dependent variables in model 1. Furthermore, in model 2, the significance level is 0.000 . Because the significance level in model 2 is 0.000 less than 0.05 , means that, there is a significant influence simultaneously between the independent and the dependent variables in model 2. From these findings, it can be concluded that AC.SIZE, AC.INDP, B. SIZE, B.INDP, B.MEET simultaneously significant effect on ARL, both before and after using control variables.

Table 3. $t$ Test Result

\begin{tabular}{clcc}
\hline Model & & $\mathrm{t}$ & Sig. \\
\hline 1 & (Constant) & 2,870 & 0,005 \\
& AC.SIZE & 0,406 & 0,685 \\
& AC.INDP & 0,355 & 0,723 \\
& B.SIZE & $-3,749$ & 0,000 \\
& B.INDP & $-0,841$ & 0,403 \\
& B.MEET & 0,973 & 0,333 \\
\hline 2 & (Constant) & 2,327 & 0,022 \\
& AC.SIZE & 0,502 & 0,617 \\
& AC.INDP & 0,433 & 0,666 \\
& B.SIZE & $-2,770$ & 0,007 \\
& B.INDP & $-0,031$ & 0,976 \\
& B.MEET & 0,668 & 0,505 \\
& F.SIZE & 1,518 & 0,132 \\
& LOSS & 0,540 & 0,591 \\
& BIG4 & $-3,887$ & 0,000 \\
\hline
\end{tabular}

Source: SPSS

Audit Committee Size. It known that in model 1, the significance level is 0.685 of AC.SIZE. Because the significance level is 0.685 more than 0.05 , it means that there is no significant effect between AC.SIZE and ARL in model 1. Furthermore, in model 2, the significance level of 
AC.SIZE has decreased 0.068 to 0.617 . Because the significance level is 0.617 more than 0.05 , it means that there is no significance effect between AC.SIZE and ARL in model 2 even though there a decrease in significance level of model 1 of 0.068 .

Audit Committee Independent. It known that in model 1, the AC.INDP significance magnitude is 0.723. Because it is more than 0.05, it means that there is no significance effect between AC.INDP and ARL in model 1. Furthermore, in model 2, the significance level of AC.INDP has decreased from 0.057 to 0.666 . Because the significance level is 0.666 more than 0.05 , it means that there is no significant effect between AC.INDP and ARL in model 2 even though there is a decrease 0,057 in the significance level of model 1.

Board Size. It known that in model 1, the significance magnitude of B. SIZE is 0,000 . Because the significance level is 0.000 less than 0.05 , it can interpreted that there is a significant effect between B.SIZE and ARL in model 1. In model 2, the significance magnitude has increased 0.007 to 0.007 of B. SIZE. Because the significance level is 0.007 less than 0.05 , so there is a significant effects between B.SIZE and ARL in model 2 even though there is an increase 0.007 in the significance level of model 1.

Board independent. It known that in model 1, the significance level is 0.403 of B.INDP. Because the significance level is 0.403 more than 0.05 , means that there is no significant effect between B.INDP and ARL in model 1. In model 2, the significance level of B.INDP has increased 0.573 to 0.976. Because the significance level is 0.976 more than 0.05 , it means that there no significant effect between B.INDP and ARL in model 2 even though there is an increase in the significance level 0.573 of model 1 .

Board Meeting. It known that in model 1, the significance level is 0.333 of B.MEET. Because the significance level is 0.333 more than 0.05 , it means that there is no significant effects between B.MEET and ARL in model 1. In model 2, the significance level has increased 0.172 to 0.505 of B.MEET. Because the significance level is 0.505 more than 0.05 , it means that there is no significant effect between B.MEET and ARL in model 2 even though there is an increase 0.172 in the significance level of model 1.

The control variable in this study consisted of three (3) variables. The first variable, F.SIZE. It known that the significance level is 0.135 of F.SIZE. Because the significance level is 0.135 more than 0.05, it means that there is no significant effect between F. SIZE and ARL. The second variable, LOSS. It known that the significance level is 0.591 of LOSS. Because the significance level is 0.591 more than 0.05, it means that there is no significant effect between LOSS and ARL. The third variable, BIG4. It known that the significance level is 0.000 of BIG 4. Because the significance level is 0.000 less than 0.05 , it means that there is a significant effect between BIG 4 and ARL.

Effect of Audit Committee Size (AC.SIZE) on ARL. The hypothesis test known that significance level is more than 0.05 of AC.SIZE that is 0.617. It means that no significant effect between AC.SIZE and ARL. This finding is in line with the research of Kaaroud et al. (2020), Oussii and Taktak (2018), Sultana et al. (2015), Salleh et al. (2017), Sakka and Jarboui (2015) who indicated there was no significant effect of AC.SIZE on ARL. However, contrary of those research of Habib et al. (2019); Nehme et al. (2015); Raweh (2019); Durand, G. (2019); Firnanti and Karmudiandri (2020); Aslam et al. (2017); Sari et al. (2019) which indicates a significant effect of AC.SIZE and ARL. The large number of audit committees means that there are many resources to help the functions' of board. However, this finding does not speed up the audit process who carried out by the auditors. It can happen if the audit committee only focuses on company's financial statements that be completed as soon as possible after closing date of the book on 31 December. The crucial thing is financial statement that has audited by the auditor because the audited financial statement will published and be important information for stakeholders. This error can lead to poor 
communication between auditors and audit committee and those problems faced by auditors are not immediately addressed. Therefore, the small or large number of audit committees has no effect on ARL.

Effect of Audit Committee Independent (AC.INDP) on ARL. The hypothesis test known that significance level is more than 0.05 of AC.INDP that is 0.666 . It means that no significant effects found between AC.INDP and ARL. This finding is in line with the research of Aljaaidi et al. (2015); Salleh et al. (2017); Oussii and Taktak (2018); Raweh et al. (2019); Firnanti and Karmudiandri (2020), which indicate that AC.INDP has no significant effect with ARL. However, contrary to the research of Nehme et al. (2015); Durand, G. (2019); Aslam et al. (2017); Sultana et al. (2015) which indicates that AC.INDP has a significant effect on ARL. There are more audit committee independent than audit committee non-independent in financial sector firms should make it easier for auditors to carry out the audit process, because fraud in financial statements can minimized when the audit committee is more independent. In fact, this finding show the existence of more audit committee independent cannot reduce the time needed in the audit process. This is probably because the selection of audit committee independent member is only a prerequisite for being sure of the POJK. As a result, performance is less than optimal, and the objective of selecting the independent audit committee itself cannot implement properly. Therefore, few or many audit committee independent ratios have no effect on ARL.

Effect of board size (B.SIZE) on ARL. The hypothesis test known that significance level is more than 0.05 of B.SIZE that is 0.007 . It was found that there was a significant effect between B.SIZE and ARL. This finding is in line with Al Daoud et al. (2015); Nehme et al. (2015); Sakka and Jarboui (2015); Alfraih, MM (2016); Firnanti and Karmudiandri (2020); which indicates a significant effect of B.SIZE with ARL. However, contrary to research by Durand, G. (2019); Habib et al. (2019); which indicates that there is no significant effect of B.SIZE with ARL. The large number of board in the financial sector firms proven to accelerate the time required by auditors to carry out the audit process. This is because the large number of board make stronger or more powerful in supervising the firms, reducing unnecessary things, and making easier to facilitate auditors in carrying out the audit process. The more of board will make less responsibility that assumed for each board, instead of good communication with the auditors in relation to the audit process. Good communication will facilitate the audit process carried out by auditors, and will have an impact on reducing ARL.

Effect of board independent (B.INDP) on ARL. The hypothesis test known that the significance level is more than 0.05 of B.INDP that is 0.976 . It means no significant effect between B.INDP and ARL. This finding is in line with Nehme et al. (2015); Oussii and Taktak (2018); Sari et al. (2019); Kaaroud et al. (2020); Sakka and Jarboui (2015), which indicated that there was no significant effect of B.INDP with ARL. However, contrary to the research of Firnanti and Karmudiandri (2020), Al Daoud et al. (2015); Habib et al. (2019); Durand, G. (2019); Alfraih, MM (2016) which indicates a significant effect of BC.INDP with ARL. There is no guarantee that there are more board independent than board non-independent in financial sector firms that can affect the time it takes for auditors to carry out the audit process. This could happen because the board independent may not have had an objective decision, only following the decision of board non-independent. Therefore, the existence of board independent looks the same as board nonindependent, so it does not affect the audit process carried out by the auditor. Another thing that might happen is that the audit quality demanded by the board independent is the same as that of the non-board independent, because both board independent and board non-independent want to maintain their own good name, so it does not affect ARL. Therefore, the ratio of the board independent little or has no effect on ARL.

Effect of board meeting (B.MEET) on ARL. The hypothesis test known that significance level is more than 0.05, of B.MEET that is 0.666. It means there was no significant effect between B.MEET and ARL. This finding is in line with Habib et al. (2019); Nehme et al. (2015) which 
indicates that there is no significant effect of B.MEET with ARL. However, contrary to the research of Firnanti and Karmudiandri (2020); Al Daoud et al. (2015) which indicates that B.MEET has a significant effect on ARL. The board meeting of financial sector firms is more than the minimum set by the POJK. It should be one of factors that can speed up the audit process, but this is not proven in this study. In this case, it is possible that the meeting are held by board was less effective and efficient. So, the meeting did not find any information related to financial statements and audit process, so there were no problems are found in the financial statements of funds that would become an obstacle to audit process. Therefore, many or least the number of board meeting cannot shorten or extend the ARL in one year.

\section{CONCLUSION}

Audit committee size (AC.SIZE) is total number of audit committees in firms. Based on hypothesis test, there was no significant effect between AC.SIZE and ARL. It concluded that large number of audit committee in financial sector firms does not affect the length of time required by the auditor to complete the audit report. Audit committee independent (AC.INDP) is independent audit committee ration in firms. Based on hypothesis test, there was no significant effect between AC.INDP and ARL. It concluded size of audit committee independent ratio on financial sector firms does not affect the length of time required by the auditor to complete the audit report. Board Size (B.SIZE) is total number in firms. Based on the hypothesis test, there was a significant effect between B.SIZE and ARL. It shows that large number of board in financial sector firms can affect the length of time taken for auditors to complete their audit reports. Furthermore, the amount of B coefficient is negative; more number of board can reduce the time required for the auditor to complete the audit report.

Board Independent (B.INDP) is board independent ratio in firms. Based on hypothesis test, there was no significant effect between B.INDP and ARL. So it can be concluded that size of board independent ratio to financial sector firms does not affect the length of time taken for auditors to complete their audit reports. Board meeting (B.MEET) is the intensity of board meeting in oneyear period. Based on the hypothesis test, there was no significant effect between B.MEET and ARL. So it can be concluded that intensity of board meeting in one year in financial sector firms has no effect on the length of time taken for auditors to complete their audit reports.

\section{REFERENCE}

Abernathy, J.L., M. Barnes, C. Stefaniak, dan A. Weisbarth. (2017). An international perspective on audit report lag: a synthesis of the literature and opportunities for future research. International Journal of Auditing. Vol.21 No.1: 100-127.

Agoes, S. dan I. C. Ardana. (2014). Etika Bisnis dan Profesi: Tantangan Membangun Manusia Seutuhnya. Edisi Revisi. Jakarta: Salemba Empat.

Al Daoud, K. A., K. N. I. K. Ismail, dan N. A. Lode. (2015). The impact of internal corporate governance on the timeliness of financial reports of Jordanian firms: Evidence using audit and management report lags. Mediterranean Journal of Social Sciences. 6(1): 430.

Alfraih, M. M. 2016. Corporate governance mechanisms and audit delay in a joint audit regulation. Journal of Financial Regulation and Compliance.

Aljaaidi, K.S., G. S. Bagulaidah, N. A. Ismail, dan F. H. Fadzil. (2015). An Empirical Invistigation of Determinants Associated with Audit Report Lag in Jordan. Jordan Journal of Business Administration. 11(4).

Aslam, S., M. A. M. Makki, dan S. M. J. Iqbal. (2017). Driving forces behind Audit Report Lag: A comparison between Auditor Independence and Knowledge Spillovers. Paradigms. 11(2): 151-157. 
Ayemere, I. L. dan A. Elijah. (2015). Corporate attributes and audit delay in emerging markets: empirical evidence from Nigeria. International Journal of Business and Social Research. 5(3): 1-10.

Abdillah, M. R., A. W. Mardijuwono, dan H. Habiburrochman. (2019). The effect of company characteristics and auditor characteristics to audit report lag. Asian Journal of Accounting Research.

Azami, Z. dan T. Salehi. (2017). The relationship between audit report delay and investment opportunities. Eurasian Business Review. 7(3): 437-449.

Baatwah, S. R., Z. Salleh, dan J. Stewart. 2019. Audit committee chair accounting expertise and audit report timeliness. Asian Review of Accounting.

Chandrarin, G. (2017). Metode Riset Akuntansi : Pendekatan Kuantitatif. Jakarta: Salemba Empat.

Darmadji, T., H.M. Fakhruddin. (2015). Pasar Modal Di Indonesia: Pendekatan Tanya Jawab. Edisi 3. Jakarta: Salemba Empat.

Durand, G. (2019). The determinants of audit report lag: a meta-analysis. Managerial Auditing Journal.

Firnanti, F. dan A. Karmudiandri. (2020). Corporate Governance and Financial Ratios Effect on Audit Report Lag. Acc. Fin. Review. 5 (1): $15-21$.

Ghafran, C. dan S. Yasmin. (2018). Audit committee chair and financial reporting timeliness: A focus on financial, experiential and monitoring expertise. International Journal of Auditing. 22(1): 13-24.

Habib, A., M. B. U. Bhuiyan, H. J. Huang, dan M. S. Miah. (2019). Determinants of audit report lag: A meta-analysis. International Journal of Auditing, 23(1): 20-44.

Hasballah, H. S. dan F. Ilyas. 2019. The Substitution Role of Audit Committee Effectiveness and Audit Quality in Explaining Audit Report Lag. Acc. Fin. Review. 4(1): 28-37.

Hussin, W.N.W., H. M. Bamahros, dan S. N. Shukeri. (2018). Lead engagement partner workload, partner-client tenure and audit reporting lag. Managerial Auditing Journal.

Kaaroud, M.A., N. M. Ariffin, dan M. Ahmad. (2020). The extent of audit report lag and governance mechanisms. Journal of Islamic Accounting and Business Research.

Kurniawan, W. (2012). Corporate Governance Dalam Aspek Hukum Perusahaan. Jakarta: PT. Pustaka Utama Grafiti.

Nehme, R., G. Assaker, dan R. Khalife. (2015). Dynamics of Audit Lag-Board of Directors and Audit Committees' Effect. Corporate Ownership and control. 12(3): 281-294.

Ocak, M. dan E. Ozden. (2018). Signing Auditor-Specific Characteristics And Audit Report Lag: A Research From Turkey. Journal of Applied Business Research.

Oussii, A. A. dan N. B. Taktak. (2018). Audit committee effectiveness and financial reporting timeliness. African Journal of Economic and Management Studies.

Raweh, N. A. M., H. Kamardin, dan M. Malik. (2019). Audit Committee Characteristics and Audit Report Lag: Evidence From Oman. International Journal of Accounting and Financial Reporting. 9(1): 152-169.

Sakka, I. F. dan A. Jarboui. (2015). External auditor's characteristics, corporate governance and audit reporting quality. International Journal of Accounting and Economics Studies. 3(2): 109-116.

Salleh, Z., S. R. Baatwah, dan N. Ahmad. (2017). Audit committee financial expertise and audit report lag: Malaysia further insight. Asian Journal of Accounting and Governance. 8: 137150.

Sari, W.O.I., B. Subroto, dan A. Ghofar. (2019). Corporate governance mechanisms and audit report lag moderated by audit complexity. International Journal of Research in Business and Social Science (2147-4478). 8(6): 256-261.

Serfiyani, C.Y., R.S.D. Purnomo, dan I. Hariyani. (2017). Capital Market Top Secret: Ramuan Sukses Bisnis Pasar Modal Indonesia. Yogyakarta: Andi.

Shukeri, S.N., W. N. Wan-Hussin, dan N. Aripin. (2015). Signing auditor quality and audit delay: Preliminary evidence. Advanced Science Letters. 21(6): 2007-2010.

Sultana, N., H. Singh, dan J. L. M. Van der Zahn. (2015). Audit committee characteristics and audit report lag. International Journal of Auditing. 19(2): 72-87. 
Supriyono, R. A. (2018). Akuntansi Keperilakuan. Yogyakarta: Gadjah Mada University Press.

Ulum, I. (2017). Intellectual Capital: Model Pengukuran, Framework Pengungkapan \& Kinerja Organisasi. Malang: Universitas Muhammadiyah Malang.

Yakub. (2012). Pengantar Sistem Informasi. Yogyakarta: Graha Ilmu. 